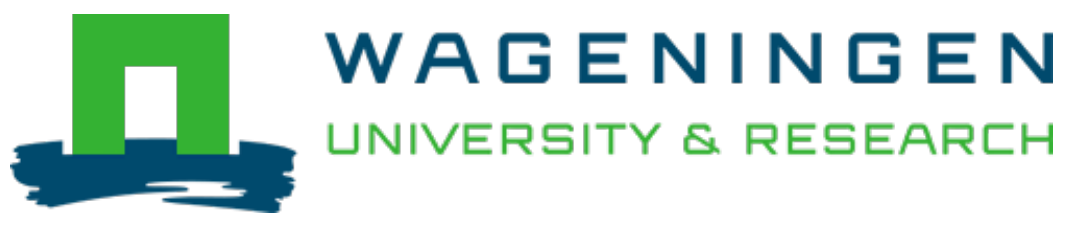

\title{
In vitro digestibility of processed and fermented soya bean, cowpea and maize
}

Journal of the Science of Food and Agriculture

Kiers, J.L.; Nout, M.J.R.; Rombouts, F.M.

https://doi.org/10.1002/1097-0010(200007)80:9<1325::AID-JSFA648>3.0.CO;2-K

This publication is made publicly available in the institutional repository of Wageningen University and Research, under the terms of article $25 \mathrm{fa}$ of the Dutch Copyright Act, also known as the Amendment Taverne. This has been done with explicit consent by the author.

Article $25 \mathrm{fa}$ states that the author of a short scientific work funded either wholly or partially by Dutch public funds is entitled to make that work publicly available for no consideration following a reasonable period of time after the work was first published, provided that clear reference is made to the source of the first publication of the work.

This publication is distributed under The Association of Universities in the Netherlands (VSNU) 'Article $25 \mathrm{fa}$ implementation' project. In this project research outputs of researchers employed by Dutch Universities that comply with the legal requirements of Article $25 \mathrm{fa}$ of the Dutch Copyright Act are distributed online and free of cost or other barriers in institutional repositories. Research outputs are distributed six months after their first online publication in the original published version and with proper attribution to the source of the original publication.

You are permitted to download and use the publication for personal purposes. All rights remain with the author(s) and / or copyright owner(s) of this work. Any use of the publication or parts of it other than authorised under article $25 \mathrm{fa}$ of the Dutch Copyright act is prohibited. Wageningen University \& Research and the author(s) of this publication shall not be held responsible or liable for any damages resulting from your (re)use of this publication.

For questions regarding the public availability of this publication please contact openscience.library@wur.nl 


\title{
In vitro digestibility of processed and fermented soya bean, cowpea and maize
}

\author{
Jeroen L Kiers,* Robert MJ Nout and Frans M Rombouts \\ Laboratory of Food Microbiology, Agrotechnology and Food Sciences, Wageningen University, Bomenweg 2, NL-6703 HD Wageningen, \\ The Netherlands
}

\begin{abstract}
Tropical legumes, ie soya bean and cowpea, were pre-treated and subsequently fermented using pure cultures of Rhizopus spp. Impact of soaking, cooking and fermentation of the legumes on their digestibility was determined using an in vitro digestion method. Processing of white maize included, amongst others, natural lactic acid fermentation, cooking and saccharification using barley malt. An in vitro method was standardised to carry out comparative determinations of the dry matter digestibility of cereal and legume food samples as a function of processing conditions, without attempting to exactly mimic gastrointestinal digestion. Using this method based on upper digestive tract digestion, it was observed that digestibility of the legumes increased during cooking and fermentation. Cooking improved the total digestibility of both soya bean and cowpea from 36.5 to $44.8 \%$ and from 15.4 to $40.9 \%$ respectively. Subsequent fungal fermentation increased total digestibility only by about $3 \%$ for both soya bean and cowpea. Digestibility was also influenced by fungal strain and fermentation time. Cooking and subsequent saccharification using malt almost tripled total digestibility of white maize from 25.5 to $63.6 \%$, whereas lactic fermentation of maize had no effect on in vitro dry matter digestibility. Although total digestibility of cooked legumes was only slightly improved by mould fermentation ( $3 \%$ for both soya bean and cowpea), the level of water-soluble dry matter of food samples increased during fermentation with Rhizopus oryzae from 7.0 up to $27.3 \%$ for soya bean and from 4.3 up to $24.1 \%$ for cowpea. These fermented products could therefore play a role as sources of easily available nutrients for individuals suffering from digestive disorders.
\end{abstract}

(C) 2000 Society of Chemical Industry

Keywords: in vitro digestibility; soya bean; cowpea; maize; processing; Rhizopus; tempe

\section{INTRODUCTION}

Legumes and cereals are rich in nutrients and bioactive substances, but they also contain various indigestible constituents such as non-starch polysaccharides, as well as antinutritional factors (ANFs) such as trypsin inhibitors and phytic acid. Various processing methods such as soaking, dehulling, germination, ${ }^{1,2}$ cooking, ${ }^{3}$ extrusion ${ }^{4,5}$ and fermentation ${ }^{6-10}$ have been reported to achieve improvements in nutritional value and digestibility.

Tempe is a traditional Indonesian fungal fermented food made from dehulled, soaked and cooked soya beans inoculated with Rhizopus sp. Tempe has high levels of protein and unsaturated lipids, has a pleasant flavour and texture and has been reported to be easily digestible. $^{6-8}$ The digestibility of tempe might be caused by enzymatic degradation of soya bean polymeric substances resulting in soluble solids, particularly soluble nitrogenous compounds, by the mould during fermentation. ${ }^{8}$ Occasionally other legumes or cereals are used for tempe fermentation. ${ }^{7,8,11}$ Kalavi et $a l^{12}$ reported a significantly higher growth rate, shorter duration of diarrhoeal episodes and shorter rehabilita- tion period in a group of children suffering from protein energy malnutrition supplemented with a porridge containing tempe and yellow maize, compared to a similar porridge made of milk and yellow maize.

In vitro digestibility studies have been carried out previously. The methods were designed to monitor specific compounds such as water-soluble dry matter, starch, protein $^{13,14}$ or non-digestible materials. ${ }^{15}$ Alternative methods were developed aimed at simulating the complete human gastrointestinal tract. ${ }^{16}$

From a food technology point of view a laboratory method was required to enable comparative assessment of the effect of food processing parameters on solubility and enzymatic degradability of foods at intermediate processing stages as well as in the final product. We developed a modular in vitro digestion method that enables differentiation of various aspects of digestibility such as solubility, degradability and absorbability. This investigation reports the influence of processing and fermentation on in vitro dry matter digestibility of soya bean, cowpea and maize.

*Correspondence to: Jeroen L Kiers, Laboratory of Food Microbiology, Agrotechnology and Food Sciences, Wageningen University, Bomenweg 2, NL-6703 HD Wageningen, The Netherlands

(Received 9 July 1999; revised version received 4 January 2000; accepted 17 February 2000) 


\section{MATERIALS AND METHODS \\ Micro-organisms}

Rhizopus microsporus var oligosporus LU 575 (NRRL 5905) and Rhizopus oryzae LU 582 were grown on malt extract agar (Oxoid, CM 59). Sporangiospore suspensions were obtained by scraping off the sporangia from a slant culture after 7 days incubation at $30^{\circ} \mathrm{C}$ and suspending them in sterile distilled water with $0.85 \% \mathrm{NaCl}$ and $0.1 \%$ peptone. The viable count varied between $10^{5}$ and $10^{6}$ colony-forming units (cfu) $\mathrm{ml}^{-1}$ when determined on Rose-Bengal Chloramphenicol Agar (Oxoid, CM 549).

An unidentified strain of Lactobacillus sp predominating in natural fermented maize was isolated and maintained on de Man, Rogosa and Sharpe (MRS) medium (Merck, 1.10661) to which $12 \mathrm{~g}$ agar was added per litre.

\section{Processing of soya bean and cowpea}

Dehulled yellow-seeded soya bean (Glycine max) and non-dehulled cowpea (Vigna unguiculata) were soaked overnight in tapwater during three cycles of accelerated acidification. ${ }^{17}$ Subsequently the beans and peas were washed with tapwater, cooked in fresh tapwater for $20 \mathrm{~min}$ (ratio beans/water of 1:3), cooled and superficially dried at room temperature. At this stage the cooked cowpeas were mildly squeezed to release the hulls, yielding a mixture of cooked cotyledons and hulls. After inoculation with the sporangiospore suspension $(1 \% \mathrm{v} / \mathrm{w})$ the beans and peas $(450 \mathrm{~g})$ were packed into hard-plastic, perforated boxes $(205 \times$ $90 \times 45 \mathrm{~mm}^{-1}$ ) and incubated at $30^{\circ} \mathrm{C}$ for $44 \mathrm{~h}$.

\section{Processing of maize}

Raw white maize (Zea mays) was coarsely ground to a flour (Fritsch, type Pulverisette 14, Germany). Two optional processing schemes A and B were followed. Option A started with accelerated natural lactic fermentation (fermentation cycles of $24 \mathrm{~h}$ at $30^{\circ} \mathrm{C}$ ) of a mixture of flour and tapwater in a ratio of $40 \mathrm{~g}$ flour to $60 \mathrm{~g}$ tapwater. Tapwater was added to the acidified dough to adjust dry matter to $15 \%$ and the porridge was cooked for $10 \mathrm{~min} .{ }^{18}$ Processing option B started with cooking a mixture of raw maize flour and tapwater (15\% dry matter) for $10 \mathrm{~min}$, followed by cooling to $50-55^{\circ} \mathrm{C}$ and addition of $1 \% \mathrm{w} / \mathrm{w}$ of malted barley, maintaining the temperature at $50-55^{\circ} \mathrm{C}$ for $30 \mathrm{~min}$. After saccharification the product was autoclaved for $30 \mathrm{~min}$ at $121^{\circ} \mathrm{C}$. Fermentation of the autoclaved product was carried out by inoculating the sterile porridge with a pure culture of Lactobacillus $\mathrm{sp}$ at $10^{3} \mathrm{cfug}^{-1}$ and incubating for $24 \mathrm{~h}$ at $30^{\circ} \mathrm{C}$.

\section{Sample preparation}

Samples taken from each processing stage were freezedried and ground (Fritsch, type Pulverisette 14, Germany) using a $1.0 \mathrm{~mm}$ screen. All samples were defatted by extraction with petroleum/ether (40:60) in Soxhlet extractors. The solvent was evaporated and quantification of the total crude lipid content (CL, \% of dry weight) was carried out gravimetrically.

\section{In vitro digestion}

The in vitro digestion method consisted of two steps as outlined below and illustrated in Fig 1. The method was carried out with $5 \mathrm{~g}$ of non-defatted sample as well as with the residue obtained after defatting a $5 \mathrm{~g}$ sample.

\section{Step 1. Enzymatic degradation}

Samples (X) were suspended in distilled water $(30 \mathrm{ml})$. The samples were incubated while stirring with an

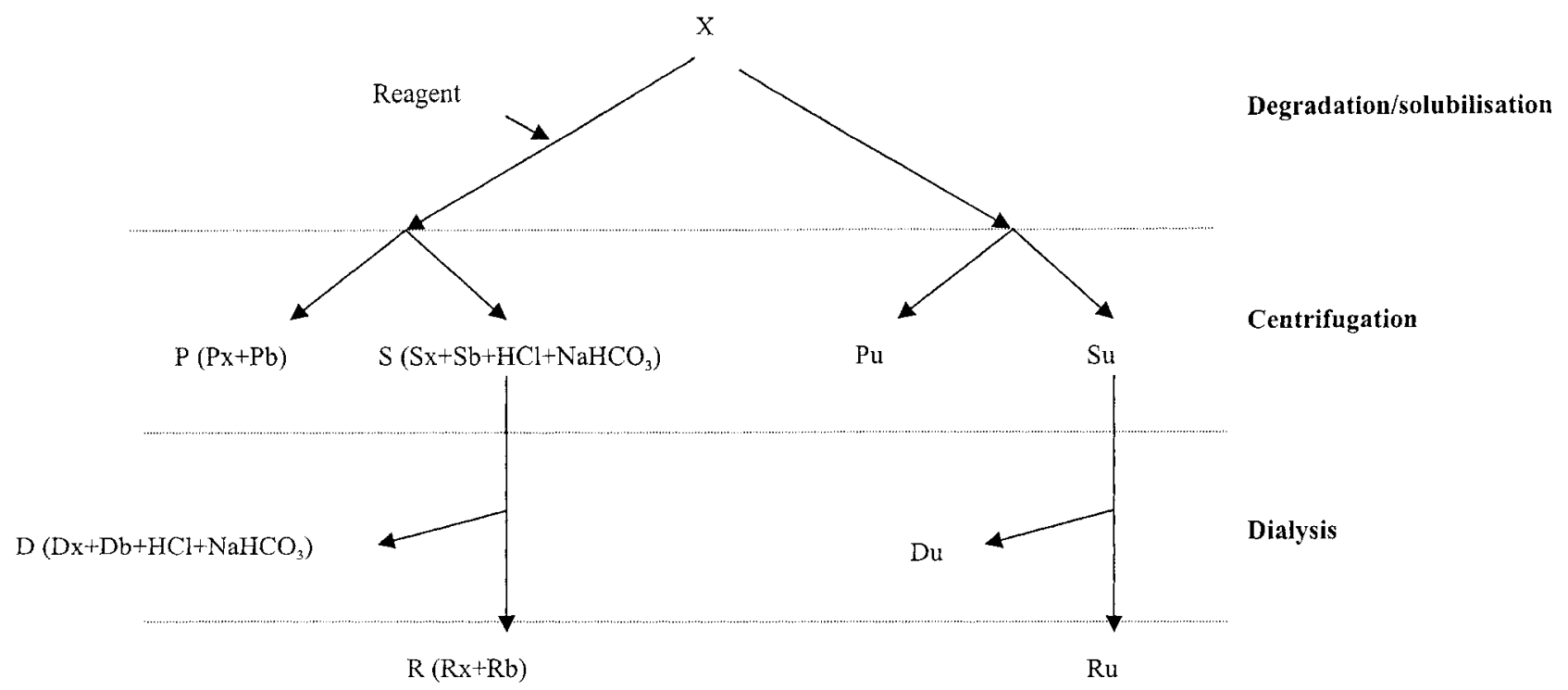

Figure 1. Flowsheet of the in vitro digestion method. All parameters are in $\mathrm{g}: \mathrm{X}$, sample; $\mathrm{P}$, pellet after degradation; $\mathrm{Px}$, part of $\mathrm{X}$ ending up in $\mathrm{P} ; \mathrm{Pb}$, part of reagent blank ending up in $\mathrm{P}$; S, supernatant after degradation; $\mathrm{Sx}$, part of $\mathrm{X}$ ending up in $\mathrm{S}$; $\mathrm{Sb}$, part of reagent blank ending up in S; $\mathrm{HCl}$, amount of $\mathrm{HCl}$ added; $\mathrm{NaHCO}_{3}$, amount of $\mathrm{NaHCO}_{3}$ added; Pu, pellet after solubilisation; Su, supernatant after solubilisation; D, dialysate of S; Dx, part of $X$ ending up in D; Db, part of reagent blank ending up in $\mathrm{D}$; Du, dialysate of $\mathrm{Su}$; R, retentate of $\mathrm{S} ; \mathrm{Rx}$, part of $\mathrm{X}$ ending up in $\mathrm{R}$; Rb, part of reagent blank ending up in $\mathrm{R}$; Ru, retentate of Su. 
$\alpha$-amylase solution $(2 \mathrm{ml})$ consisting of 12500 units $^{-1}$ $\alpha$-amylase (Sigma A-1031), $1.5 \mathrm{gl}^{-1} \mathrm{NaCl}, 1.5 \mathrm{gl}^{-1}$ $\mathrm{K}_{2} \mathrm{HPO}_{4}$ and $0.5 \mathrm{gl}^{-1} \mathrm{Na}_{2} \mathrm{CO}_{3}(\mathrm{pH} 7.0$ ) for $30 \mathrm{~min}$ at $37^{\circ} \mathrm{C}$. Next the $\mathrm{pH}$ was adjusted to 4.0 using $5 \mathrm{M} \mathrm{HCl}$ and the suspensions were incubated with $8 \mathrm{ml}$ of stomach medium $\left(0.1 \mathrm{gl}^{-1}\right.$ lipase (Amano Pharmaceuticals, Rhizopus F-AP15), $0.125 \mathrm{gl}^{-1}$ pepsin (Sigma P-6887), $3.1 \mathrm{gl}^{-1} \mathrm{NaCl}, 1.1 \mathrm{gl}^{-1} \mathrm{KCl}$, $0.6 \mathrm{gl}^{-1} \mathrm{Na}_{2} \mathrm{CO}_{3}, 0.11 \mathrm{gl}^{-1} \mathrm{CaCl}_{2}, \mathrm{pH} 4.0$ ) for $1 \mathrm{~h}$ at $37^{\circ} \mathrm{C}$. The $\mathrm{pH}$ was then adjusted to 6.0 using solid $\mathrm{NaHCO}_{3}$. Finally, $10 \mathrm{ml}$ of a $2 \%$ pancreatic solution (20.0 $\mathrm{gl}^{-1}$ pancreatin (Sigma P-1750), $5.0 \mathrm{gl}^{-1}$ bile (Sigma B-3883), $5.0 \mathrm{gl}^{-1} \mathrm{NaCl}, 0.68 \mathrm{gl}^{-1} \mathrm{KH}_{2} \mathrm{PO}_{4}$, $0.3 \mathrm{gl}^{-1} \mathrm{Na}_{2} \mathrm{HPO}_{4}, 0.84 \mathrm{gl}^{-1} \mathrm{NaHCO}_{3}$ ) was added and the suspensions were incubated for $30 \mathrm{~min}$ at $37^{\circ} \mathrm{C}$. Subsequently the suspensions were centrifuged at $3000 \times g$ for $15 \mathrm{~min}$ at $4^{\circ} \mathrm{C}$. The supernatant was decanted and the pellet was washed twice in $20 \mathrm{ml}$ of distilled water. Supernatants obtained were pooled and aliquots were taken for dry matter content determination by drying for $24 \mathrm{~h}$ at $80^{\circ} \mathrm{C}$ in triplicate, resulting in $S$ (g). The pellet was freeze-dried to determine its dry weight $\mathrm{P}(\mathrm{g})$.

\section{Step 2. Dialysis}

In the absence of an in vivo epithelial uptake situation we adopted dialysis as a physical separation technique and we have chosen a dialysis membrane of a rather standard cut-off number to distinguish solubles of relatively low and high molecular mass/size. Obviously this is not identical to the different uptake processes taking place in the small intestine.

Supernatants were transferred into dialysis tubes (Medicell Int Ltd, Visking, size 8 (25.4 mm), cut-off $12-14 \mathrm{kDa}$ ) and dialysed against running tapwater for $15 \mathrm{~h}$ at $4^{\circ} \mathrm{C}$. Retentates were quantitatively collected and their dry matter content was determined by drying aliquots for $24 \mathrm{~h}$ at $80^{\circ} \mathrm{C}$ in triplicate, resulting in $\mathrm{R}$ (g).

\section{Corrections and blank}

$\mathrm{S}$ (g) was corrected for added $\mathrm{HCl}$ (g) and $\mathrm{NaHCO}_{3}$ (g). In the in vitro digestion procedure a reagent blank was included, resulting in $\mathrm{Sb}$ (g) expressing the amount of reagent that is soluble, $\mathrm{Pb}(\mathrm{g})$ expressing the amount of reagent that is insoluble and $\mathrm{Rb}(\mathrm{g})$ expressing the amount of reagent that is retained after dialysis.

Solubility and absorbability without enzymatic treatment To determine solubility and absorbability without enzymatic treatment, defatted samples (X) were solubilised in $30 \mathrm{ml}$ distilled water, incubated while stirring at $37^{\circ} \mathrm{C}$ for $30 \mathrm{~min}$ and centrifuged as described above, resulting in $\mathrm{Su}$ (g) and $\mathrm{Pu}(\mathrm{g})$. Supernatants were dialysed as described above. The dry matter content of the retentate obtained was determined as described earlier and resulted in $\mathrm{Ru}(\mathrm{g})$.

\section{Calculations}

In the absence of an in vivo situation we arbitrarily defined the following parameters. Solubility was defined as the percentage of a defatted sample that is water-soluble $((\mathrm{Su} / \mathrm{X}) \times 100 \%$ or $[(\mathrm{X}-\mathrm{Pu}) / \mathrm{X}] \times$ $100 \%)$. The percentage of a defatted sample that was able to pass the dialysis tube without being treated with digestive enzymes was defined as absorbability $([(\mathrm{Su}-\mathrm{Ru}) / \mathrm{X}] \times 100 \%$ or $[(\mathrm{X}-\mathrm{Pu}-\mathrm{Ru}) / \mathrm{X}] \times 100 \%)$. Similarly, the percentage of a defatted sample that was able to pass the dialysis tube after enzymatic degradation was defined as digestibility $\left(\left\{\left[\left(\mathrm{S}-\mathrm{Sb}-\mathrm{HCl}-\mathrm{NaHCO}_{3}\right)-(\mathrm{R}-\mathrm{Rb})\right] / \mathrm{X}\right\} \times 100 \%\right.$ or $\{[\mathrm{X}-(\mathrm{P}-\mathrm{Pb})-(\mathrm{R}-\mathrm{Rb})] / \mathrm{X}\} \times 100 \%)$, and in the case of non-defatted samples these formulas defined total digestibility. In the case of defatted samples, total digestibility was expressed as the sum of the crude lipid (CL, \%) and digestibility (\%) (CL+[(100-CL)/ $100] \times$ digestibility) assuming $100 \%$ digestion of CL.

As shown above, all parameters could be calculated in two ways, directly or indirectly. All results shown in this paper were obtained by direct calculation. Indirect calculations were performed to confirm the values obtained after direct calculations, but these data are not shown.

\section{Coefficients of variation}

Crude lipid, solubility and absorbability values presented in this study are the result of single determinations. When interpreting the data, one has to take into account the coefficients of variation of these analyses, respectively $1.7 \%, 3.5 \%$ and $9.0 \%$. Digestibility determinations were carried out in duplicate.

\section{RESULTS \\ pH changes during processing}

Changes in $\mathrm{pH}$ during processing of soya bean and cowpea are shown in Table 1 . Soaking with the accelerated acidification technique gave a $\mathrm{pH}$ of 4.2 and 4.1 for soya bean and cowpea respectively. Cooking resulted in an increase in $\mathrm{pH}$ to 4.9 for both substrates. Fungal fermentation generally resulted in $\mathrm{pH}$ increase as illustrated by maximum $\mathrm{pH}$ levels of 6.7 and 5.8 obtained in soya bean and cowpea fermented with Rhizopus oryzae LU 582 and Rhizopus oligosporus LU 575 respectively. Although not necessarily correlated, these $\mathrm{pH}$ changes were in accordance with comparative fungal growth activities that were measured by evolution of metabolic heat (data not shown).

Accelerated natural fermentation of maize by backslopping resulted in a pH of 3.7 (Table 2). Using a starter culture of Lactobacillus $\mathrm{sp}$, a similar $\mathrm{pH}$ decrease was seen after fermentation of the autoclaved material for $24 \mathrm{~h}$ at $30^{\circ} \mathrm{C}$ (final $\log _{10} \mathrm{cfug}^{-1}=10.4$ ).

\section{Crude lipid content}

Percentages of crude lipid content on a dry weight basis are shown in Tables 1 and 2. Due to soaking and 
Table 1. Characteristics of processed and fermented soya bean and cowpea. Data represent single determinations

\begin{tabular}{|c|c|c|c|c|c|c|}
\hline & \multicolumn{3}{|c|}{ Soya bean } & \multicolumn{3}{|c|}{ Cowpea } \\
\hline & $p H$ & $\begin{array}{l}\text { Crude lipid } \\
\text { (\% dry matter) }\end{array}$ & $\begin{array}{c}\text { Solubility } \\
\text { (\% fat-free dry matter) }\end{array}$ & $p H$ & $\begin{array}{l}\text { Crude lipid } \\
\text { (\% dry matter) }\end{array}$ & $\begin{array}{c}\text { Solubility } \\
\text { (\% fat-free dry matter) }\end{array}$ \\
\hline $\mathrm{R}^{\mathrm{a}}$ & 6.8 & 20.0 & 64.3 & 6.5 & 0.8 & 30.6 \\
\hline$S$ & 4.2 & 26.5 & 18.7 & 4.1 & 1.6 & 9.8 \\
\hline SC & 4.9 & 28.9 & 7.0 & 4.9 & 1.5 & 4.3 \\
\hline SC575,24 & 5.6 & 28.9 & 18.5 & 5.2 & 1.5 & 13.1 \\
\hline SC575,44 & 5.7 & 29.5 & 20.2 & 5.8 & 2.0 & 19.4 \\
\hline SC582,24 & 6.4 & 28.2 & 27.3 & 5.0 & 2.2 & 17.0 \\
\hline SC582,44 & 6.7 & 25.9 & 23.1 & 4.9 & 4.8 & 24.1 \\
\hline
\end{tabular}

${ }^{a}$ R, raw; S, soaked; C, cooked; 575, fermented with Rhizopus oligosporus LU 575; 582, fermented with Rhizopus oryzae LU 582; 24 , fermented for $24 \mathrm{~h} ; 44$, fermented for $44 \mathrm{~h}$.

Table 2. Characteristics of processed and fermented maize

\begin{tabular}{lccc}
\hline & \multicolumn{2}{c}{$\begin{array}{c}\text { Crude lipid } \\
\text { (\% dry matter) }\end{array}$} & $\begin{array}{c}\text { Solubility } \\
\text { (\% fat-free dry matter) }\end{array}$ \\
\hline $\mathrm{R}^{\mathrm{a}}$ & 5.6 & 4.0 & 5.6 \\
$\mathrm{~S}$ & 3.7 & 4.0 & 4.6 \\
$\mathrm{SC}$ & 3.8 & 2.8 & 5.4 \\
$\mathrm{C}$ & 5.7 & 2.8 & 6.1 \\
$\mathrm{M}$ & 5.8 & 3.4 & 73.6 \\
$\mathrm{CMA}$ & 5.9 & 3.4 & 70.9 \\
CMAL & 3.8 & 3.6 & 68.9 \\
\hline
\end{tabular}

a See Table 1; M, malted; A, autoclaved; L, fermented with Lactobacillus sp.

cooking of soya bean, the crude lipid content increased markedly. Fermentation of soya bean with LU 575 slightly increased the crude lipid content to $29.5 \%$, and with LU 582 it decreased to $25.9 \%$. Fermentation of cowpea with these moulds appeared to increase the total crude lipid content, even up to $4.8 \%$ for LU 582 .

\section{Solubility}

Solubility was reduced markedly in soaked and cooked soya beans and cowpeas (Table 1). During subsequent fermentation of soya bean and cowpea, solubility increased up to two to six times compared to the cooked samples. LU 582 resulted in higher solubility than LU 575.
Solubility of maize was hardly affected by cooking and fermentation (Table 2). Malting of cooked maize, however, resulted in a 12 -fold increased solubility.

\begin{abstract}
Absorbability and digestibility
In Table 3, absorbability and digestibility of processed and fermented soya bean, cowpea and maize are shown. For soya bean and cowpea, both absorbability and digestibility decreased after soaking. However, in cooked samples, digestibility was increased whereas absorbability continued to decrease. Fermentation of soya bean resulted in considerable increases in absorbability, but digestibility only increased slightly. For cowpea this was even more pronounced. Whereas cooking of maize resulted in high digestibility, absorbability did not increase until saccharification of cooked maize was conducted.
\end{abstract}

\section{Total digestibility of defatted samples}

In the processed soya bean samples the crude lipid contributed most to the total digestibility (Tables 1 and 4). The highest contribution to the total digestibility of cowpea samples was derived from the digestibility (absorbable material after enzymatic degradation) component.

The decrease in total digestibility due to soaking was followed by a major increase due to cooking. During soya bean fermentation with LU 575, total digestibility

Table 3. Absorbability, digestibility and part of the digestible material that was already absorbable before enzyme treatment expressed as the ratio between absorbability and digestibility $(A / D)$, for processed and fermented soya bean, cowpea and maize. Digestibility represent the average of duplicate analysis

\begin{tabular}{|c|c|c|c|c|c|c|c|c|c|c|}
\hline & \multicolumn{3}{|c|}{ Soya bean } & \multicolumn{3}{|c|}{ Cowpea } & & \multicolumn{3}{|c|}{ Maize } \\
\hline & $\begin{array}{c}\text { Absorbability } \\
(\%)\end{array}$ & $\begin{array}{c}\text { Digestibility } \\
(\%)\end{array}$ & $A / D$ & $\begin{array}{c}\text { Absorbability } \\
(\%)\end{array}$ & $\begin{array}{c}\text { Digestibility } \\
\text { (\%) }\end{array}$ & $A / D$ & & $\begin{array}{c}\text { Absorbability } \\
(\%)\end{array}$ & $\begin{array}{c}\text { Digestibility } \\
(\%)\end{array}$ & $A / D$ \\
\hline $\mathrm{R}^{\mathrm{a}}$ & 19.7 & 28.3 & 0.7 & 13.4 & 26.1 & 0.5 & $\mathrm{R}^{\mathrm{a}}$ & 3.7 & 22.4 & 0.2 \\
\hline S & 13.7 & 13.7 & 1.0 & 8.1 & 14.1 & 0.6 & S & 3.7 & 21.0 & 0.2 \\
\hline SC & 4.8 & 22.3 & 0.2 & 3.5 & 40.0 & 0.1 & SC & 3.9 & 52.0 & 0.1 \\
\hline SC575, 24 & 7.6 & 23.7 & 0.3 & 8.1 & 41.7 & 0.2 & C & 3.3 & 52.5 & 0.1 \\
\hline SC575, 44 & 9.5 & 26.1 & 0.4 & 13.0 & 40.3 & 0.3 & $\mathrm{CM}$ & 52.4 & 62.4 & 0.8 \\
\hline SC582, 24 & 16.4 & 26.2 & 0.6 & 12.8 & 42.5 & 0.3 & CMA & 51.6 & 65.6 & 0.8 \\
\hline SC582, 44 & 14.0 & 27.2 & 0.5 & 18.6 & 39.4 & 0.5 & CMAL & 48.0 & 65.6 & 0.7 \\
\hline
\end{tabular}

a See Tables 1 and 2 . 
Table 4. Total digestibility (\% dry matter) of defatted and non-defatted soya bean, cowpea and maize

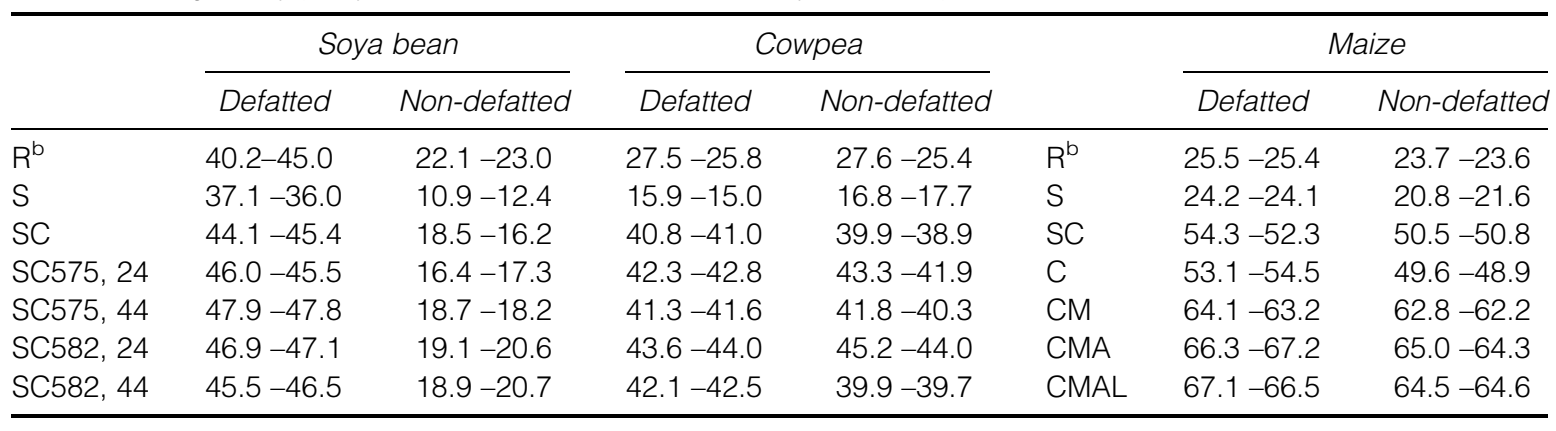

a Duplicate values.

${ }^{b}$ See Tables 1 and 2.

increased up to $47.9 \%$ after $44 \mathrm{~h}$. A similar increase in total digestibility was reached more rapidly by fermentation with LU 582. Prolonged fermentation of soya bean with LU 582 resulted in a decrease in total digestibility, caused by a considerable reduction of the crude lipid fraction. Fermentation of cowpea for $24 \mathrm{~h}$ increased total digestibility by $1.6 \%$ and $2.9 \%$ for LU 575 and LU 582 respectively. During the following $20 \mathrm{~h}$ of fermentation the total digestibility showed a decrease of $1.1 \%$ and $1.5 \%$ for LU 575 and LU 582 respectively, caused by decreases in digestibility.

Total digestibility of processed maize is shown in Table 4. Cooking resulted in the biggest increase in total digestibility, but subsequent saccharification using malt also significantly improved total digestibility. Fermentation had only minor effects on total digestibility.

\section{In vitro digestion of defatted vs non-defatted samples}

In Table 4, total digestibility of defatted and nondefatted samples is shown. The data show that the values for defatted soya bean samples are much higher than for non-defatted samples. In the case of cowpea and maize, values for total digestibility of defatted and non-defatted samples are closer.

\section{DISCUSSION}

Loss of water-soluble solids during soaking and cooking is reflected in a decrease in solubility. Nonlipid water-soluble dry matter is lost during soaking and cooking. In addition, loss of protein into the soaking water may be enhanced by the low $\mathrm{pH}$ during soaking. As a result of these dry matter losses a relative increase in crude lipid content is seen. Taking into account the coefficient of variation of the crude lipid determination $(1.7 \%)$, increased values of crude lipid of soaked and cooked legumes would reflect total dry matter losses of $28-33 \%$ for soya beans and $48-55 \%$ for cowpeas during soaking and cooking. The value found for soya bean is in accordance with dry matter losses observed in our laboratory, but the dry matter losses in cowpea are of the order of $25 \%$, implying that at low crude lipid contents estimations of dry matter losses are less accurate.

Although the dry matter losses might seem a waste, soaking is essential to increase the moisture content and to leach out several ANFs, and cooking is essential to destroy potential pathogenic bacteria, to inactivate trypsin inhibitors and to release some of the nutrients essential for mould growth. ${ }^{6}$

Acidification during the soaking of maize flour resulted in a sufficient $\mathrm{pH}$ decrease to contribute significantly to food safety. Upon fermentation of maize and other cereals, nutritional benefits such as degradation of ANFs, increased mineral bioavailability, improvement in protein digestibility and degradation of flatulence-causing oligosaccharides may result. $^{9}$

\section{Tempe fermentation of soya bean and cowpea}

During tempe fermentation the fermenting microorganisms, mainly Rhizopus spp, induce many compositional changes, including degradation of protein, lipid and carbohydrates, catalysed by a variety of fungal proteases, lipases and carbohydrases. ${ }^{19}$ In addition, a decrease in ANFs is associated with the action of the moulds and their enzymes. ${ }^{20}$

Generally a $\mathrm{pH}$ increase is observed resulting from protein degradation and liberation of ammonia. ${ }^{6}$ However, there are significant differences between Rhizopus spp and between the substrates in regard to $\mathrm{pH}$ changes and substrate modifications. ${ }^{21}$ This is also shown by our present data.

Changes in crude lipid content during fermentation might result from metabolic activity such as assimilation and synthesis, as well as from changes in non-lipid dry matter. ${ }^{19,22}$

\section{Solubility}

The less pronounced decrease in solubility in the case of cowpea can be attributed to the presence of the cowpea seed coat acting as a barrier to diffusion.

A marked increase in water-soluble compounds as was shown after fermentation using Rhizopus spp has been reported elsewhere for tempe fermentation. ${ }^{23}$

The high increase in solubility due to the saccharification of cooked maize can be explained mainly by 
the transformation of gelatinised starch into watersoluble dextrins, oligosaccharides, maltose and glucose.

\section{Absorbability}

The increase in absorbability due to mould fermentation and saccharification of maize was very likely due to the breakdown of macromolecular substances into water-soluble low-molecular-weight molecules, being small enough to pass the dialysis membrane without the need for further breakdown by gastrointestinal enzymes.

\section{Total digestibility}

We assume that the high crude lipid fraction found in soya bean is associated with the big difference in total digestibility of defatted and non-defatted soya bean. These differences were less pronounced in the case of cowpea and maize. In order to obtain maximum levels of total digestibility, we recommend the defatting of soya bean samples prior to in vitro digestion.

The big increase in total digestibility of maize and cowpea is probably due to the gelatinisation of the starch present in large amounts in these materials, making it more readily available for the enzymatic degradation. Processing of cowpea is essential because ANFs in raw cowpea could result in pathophysiological changes in gut morphology leading to impaired absorption of nutrients and consequently a diminished growth of eg weaning pigs. ${ }^{24}$

Although tempe fermentation did not increase the total digestibility of soya bean and cowpea to a large extent, it was shown that the amount of absorbable matter without enzymatic degradation (absorbability) increased markedly owing to mould fermentation. Digestibility of fermented legumes was only slightly improved. From the ratio between absorbability and digestibility it is also shown that mould fermentation contributed up to $50-60 \%$ of the digestibility. From this it can be concluded that mould fermentation already 'pre-digested' the material to a significant extent. Similarly, after saccharification of cooked maize with malt, hardly any additional absorbable material is produced after incubation with gastrointestinal enzymes. Saccharification using malt was confirmed to be a suitable technique for the preparation of highly digestible, nutrient-dense cereal porridges. ${ }^{25}$ These findings have particular relevance for their use in formulated foods for individuals suffering from a malfunctioning gastrointestinal physiology.

In vivo trials using rats and neonatal pigs showed only minor differences in growth, daily weight gain and protein efficiency when fermented soya beans and cowpeas were fed compared to unfermented controls. ${ }^{6,7,26-28}$ This could lead to the conclusion that fermentation of legumes using Rhizopus spp would hardly improve their in vivo digestibility in healthy rats and piglets. However, the small increase in in vitro digestibility and, even more, the large increase in absorbability caused by fermentation observed in this study could have beneficial physiological effects in the case of malfunctioning gastrointestinal digestive systems. These foods are therefore expected to offer benefits when feeding weaning pigs, or children suffering from malnutrition and/or acute diarrhoea for whom the need for easily digestible rehabilitation foods is high. The use of tempe in rehabilitation of children suffering from protein-energy malnutrition in Indonesia has already been reported by Karyadi et al, ${ }^{29}$ who showed a greater nutritional impact of food mixtures containing tempe than of those containing cooked soya beans.

\section{ACKNOWLEDGEMENTS}

The authors gratefully acknowledge the support by Numico Research BV, Wageningen, The Netherlands. The authors also thank L Lycken and L van der Burgt for their participation in developing the in vitro digestion method.

\section{REFERENCES}

1 Khetarpaul $\mathrm{N}$ and Chauhan BM, Effect of germination and fermentation on in vitro starch and protein digestibility of pearl millet. J Food Sci 55:883-884 (1990).

2 Sripriya G, Antony U and Chandra TS, Changes in carbohydrate, free amino acids, organic acids, phytate and $\mathrm{HCl}$ extractability of minerals during germination and fermentation of finger millet (Eleusine coracana). Food Chem 58:345-350 (1997).

3 Kaankuka FG, Balogun TF and Tegbe TSB, Effects of duration of cooking of full-fat soya beans on proximate analysis, levels of antinutritional factors, and digestibility by weanling pigs. Anim Feed Sci Technol 62:229-237 (1996).

4 Dahlin KM and Lorenz KJ, Carbohydrate digestibility of laboratory-extruded cereal grains. Cereal Chem 70:329-333 (1993).

5 Marsman GJP, Chemical, physical and nutritional changes in soybean meal as a result of toasting and extrusion cooking. $P h D$ Thesis, Wageningen Agricultural University (1998).

6 Steinkraus $\mathrm{KH}$, Indonesian tempe and related fermentations, in Handbook of Indigenous Fermented Foods, Ed by Steinkraus KH, Marcel Dekker, New York, pp 1-94 (1996).

7 Nout MJR and Rombouts FM, Recent developments in tempe research. F Appl Bacteriol 69:609-633 (1990).

8 Mital BK and Garg SK, Tempeh-technology and food value. Food Rev Int 6:213-224 (1990).

9 Nout MJR and Motarjemi Y, Assessment of fermentation as a household technology for improving food safety: a joint FAO/ WHO workshop. Food Control 8:221-226 (1997).

10 Nout MJR and Ngoddy PO, Technological aspects of preparing affordable fermented complementary foods. Food Control 8:279-287 (1997).

11 Djurtoft R, Cowpeas (Vigna unguiculata) used for making tempe for human consumption. F Plant Foods 4:75-76 (1982).

12 Kalavi FNM, Muroki NM, Omwega AM and Mwadime RKN, Effect of tempe-yellow maize porridge and milk-yellow maize porridge on growth rate, diarrhoea and duration of rehabilitation of malnourished children. E Afr Med $\mathcal{f}$ 73:427-431 (1996).

13 Yadav S and Khetarpaul N, Indigenous legume fermentation: effect on some antinutrients and in vitro digestibility of starch and protein. Food Chem 50:403-406 (1994).

14 Yadav S and Khetarpaul N, Effect of fermentation period and temperature on antinutrients and in vitro digestibility of starch 
and protein of wadi-an indigenous fermented legume product. F Food Sci Technol 32:132-134 (1995).

15 Lebet V, Arrigoni E and Amadò R, Digestion procedure using mammalian enzymes to obtain substrates for in vitro fermentation studies. Lebensm Wiss Technol 31:509-515 (1998).

16 Minekus M, Development and validation of a dynamic model of the gastrointestinal tract. PhD Thesis, University of Utrecht (1998).

17 Nout MJR, De Dreu MA, Zuurbier AM and Bonants-Van Laarhoven TMG, Ecology of controlled soya bean acidification for tempe manufacture. Food Microbiol 4:165-172 (1987).

18 Nout MJR, Rombouts FM and Hautvast GJ, Accelerated natural lactic fermentation of infant food formulations. Food Nutr Bull 11:65-73 (1989).

19 De Reu JC, Solid-substrate fermentation of soya beans to tempe: process innovations and product characteristics. PhD Thesis, Wageningen Agricultural University (1994).

20 Reddy NR and Pierson MD, Reduction in antinutritional and toxic components in plant foods by fermentation. Food Res Int 27:281-290 (1994).

21 Kiers JL, Schreuder J, Nout MJR and Rombouts FM, Tempe fermentation, using different substrates and pure culture starters, and the effects of substrate modification on in vitro digestibility. Proc Int Tempe Symp, Bali, pp 64-72 (1997).

22 Ruiz-Terán F and Owens JD, Chemical and enzymic changes during the fermentation of bacteria-free soya bean tempe. $\mathcal{F ~} \mathrm{Sci}$ Food Agric 71:523-530 (1996).

23 Van Buren JP, Hackler LR and Steinkraus KH, Solubilization of soybean tempeh constituents during fermentation. Cereal Chem 49:208-211 (1972).

24 Makinde MO, Umapathy E, Akingbemi BT and Mandisodza $\mathrm{KT}$, Effects of feeding different levels of cowpea (Vigna unguiculata) on gut morphology and faecal composition in weanling pigs. S Afr f Anim Sci 26:42-46 (1996).

25 Mensah P, Ndiokwelu CI, Uwaegbute A, Ablordey A, Van Boxtel AMGA, Brinkman C, Nout MJR and Ngoddy PO, Feeding of lactic acid-fermented high nutrient density weaning formula in paediatric settings in Ghana and Nigeria: acceptance by mother and infant and performance during recovery from acute diarrhoea. Int $\mathcal{F}$ Food Sci Nutr 46:353-362 (1995).

26 Smith AK, Rackis JJ, Hesseltine CW, Smith M, Robbins DJ and Booth AN, Tempeh: nutritive value in relation to processing. Cereal Chem 41:173-181 (1964).

27 Murata K, Ikehata H, Edani Y and Koyanagi K, Studies on the nutritional value of tempeh. II. Rat feeding test with tempeh, unfermented soybeans, and tempeh supplemented with amino acids. Agric Biol Chem 35:233-241 (1971).

28 Zamora RG and Veum TL, Nutritive value of whole soybeans fermented with Aspergillus oryzae or Rhizopus oligosporus as evaluated by neonatal pigs. F Nutr 118:438-444 (1988).

29 Karyadi D, Mahmud MK and Hermana, Locally made rehabilitation foods, in The Malnourished Child, Vol 19 of Nestlé Nutrition Workshop Series, Ed by Suskind RM and Lewinter-Suskind L, Raven Press, New York, pp 371-381 (1990). 